Artikel Penelitian

\title{
ANALISIS LAPORAN HASIL SURVEI AKREDITASI RUMAH SAKIT UNTUK PELAYANAN KEFARMASIAN DAN PENGGUNAAN OBAT
}

\author{
ISI MULARSIH', DJOTI ATMODJO', ARIS SUNANDAR ${ }^{2}$, SRI RACHMANI ${ }^{1}$ \\ ${ }^{1}$ Komisi Akreditasi Rumah Sakit \\ ${ }^{2}$ RSUD Kelet Provinsi Jawa Tengah
}

Email korespondensi: isimularsihsumarno@yahoo.co.id

Dikirimkan 01 Maret 2021, Diterima 19 April 2021

\begin{abstract}
Abstrak
Latar Belakang: Keberhasilan survei akreditasi dipengaruhi penyusunan laporan yang baik dari surveyor. Jumlah surveyor KARS yang cukup banyak dapat menimbulkan variasi dalam penyusunan laporan hasil survei. Saat ini evaluasi laporan survei surveyor dilakukan melalui mekanisme kontrol yang dilakukan para konselor. Evaluasi keseluruhan hasil laporan survei surveyor belum pernah dilakukan, termasuk pada layanan kefarmasian dan penggunaan obat yang merupakan pelayanan esensial dalam penanganan pasien.

Tujuan: Melakukan analisis kualitas laporan hasil survei akreditasi rumah sakit yang dilakukan surveyor pada bab Pelayanan Kefarmasian dan Penggunaan Obat (PKPO).

Metode: Penelitian observasional retrospektif dilakukan menggunakan data sekunder KARS dengan total 1.037 laporan hasil survei reguler tahun 2019. Sampel diambil sebesar 10,00\% secara purposive stratified random sampling. Terdapat lima variabel yang dievaluasi untuk menilai kualitas laporan hasil survei, yaitu: ketepatan waktu penyampaian laporan, ketepatan pemberian nilai, ketepatan penulisan fakta dan analisis, ketepatan penulisan rekomendasi, dan kejadian diskrepansi antara surveyor dan konselor. Analisis dilakukan secara deskriptif.

Hasil: Laporan hasil survei menunjukkan hasil 59,00\% tepat waktu, 71,00\% tepat pemberian nilai, 49,50\% tepat penulisan fakta dan analisis, dan $41,00 \%$ tepat penulisan rekomendasi. Diskrepansi antara surveyor dan konselor terjadi sebesar $17,00 \%$, dan diantaranya terbanyak (68,00\%) merupakan diskrepansi rekomendasi, 25,00\% diskrepansi nilai, dan 7,00\% diskrepansi fakta dan analisis.
\end{abstract}

Kesimpulan: Kualitas laporan hasil survei akreditasi untuk bab PKPO masih belum memadai, dan oleh karenanya perlu dilakukan upaya perbaikan untuk meningkatkan kualitasnya.

Kata kunci: evaluasi hasil survei, pelayanan kefarmasian dan pelayanan obat, kualitas laporan, surveyor akreditasi

\section{Latar Belakang}

Akreditasi rumah sakit merupakan salah satu mekanisme penting untuk menjaga mutu pelayanan rumah sakit di Indonesia. Pada tahun 2019, Komite Akreditasi Rumah Sakit (KARS) telah melakukan survei pada 1.045 rumah sakit (RS), termasuk delapan RS diantaranya menempuh survei Program Khusus dan rumah sakit lainnya melakukan akreditasi reguler ${ }^{1}$.

Surveyor memiliki peran utama dalam kegiatan survei akreditasi. Di tahun 2019, survei akreditasi melibatkan sejumlah 930 surveyor. Jumlah surveyor yang besar ini dapat berisiko menimbulkan variasi dalam penyusunan laporan hasil survei, meskipun para surveyor telah melalui proses seleksi dan pelatihan secara profesional untuk memastikan reliabilitas antar penilai (surveyor) ${ }^{2}$.

Salah satu keberhasilan survei dapat dilihat dari penyusunan laporan yang baik oleh para surveyor, sebagai dasar bagi KARS untuk menetapkan status akreditasi untuk RS yang telah disurvei. Kinerja surveyor merupakan inti keandalan dan validitas program akreditasi ${ }^{3}$.

Sampai saat ini, evaluasi terhadap laporan survei oleh para surveyor dilakukan melalui mekanisme yang dilakukan oleh para konselor, yang menilai pada tahap kedua hasil survei akreditasi terhadap setiap laporan hasil survei yang bersifat individual. Dengan proses dua tahap ini, maka dapat terjadi pula diskrepansi antara laporan surveyor dengan laporan konselor.

Laporan survei oleh surveyor secara umum belum pernah dilakukan dan dilaporkan, sehingga belum diketahui kualitas hasil laporan survei yang telah dilaksanakan oleh para surveyor. Mengingat pengobatan merupakan pelayanan esensial bagi pasien, maka penelitian ini memfokuskan pada Pelayanan kefarmasian dan penggunaan obat (PKPO). Penelitian yang 
bertujuan untuk menganalisis kualitas laporan hasil survei akreditasi rumah sakit yang dilakukan surveyor pada bab Pelayanan Kefarmasian dan Penggunaan Obat (PKPO).

\section{Metode}

Desain penelitian menggunakan studi observasional menggunakan data sekunder laporan hasil survei PKPO oleh surveyor tahun 2019 yang diambil dari database KARS.

Populasi penelitian adalah 1.037 laporan hasil survei reguler akreditasi rumah sakit pada tahun $2019^{4}$, dengan distribusi berdasarkan tingkat kelulusan akreditasi RS yaitu tingkat paripurna 397 RS, Utama 203 RS, Madya 273 RS dan Dasar 164 RS. Sampel sebanyak 64 RS dengan kelas rumah sakit dan tingkat kelulusan akreditasi yang berbeda dihitung menggunakan rumus Slovin dengan ketepatan 95,00\% dan margin error 5,00\%, sampel diambil dengan purposived stratified random sampling sehingga jumlah sampel dari setiap tingkat kelulusan yaitu tingkat Paripurna $25 \mathrm{RS}$, Utama $12 \mathrm{RS}$, Madya 17 RS, dan Dasar 10 RS.
Tabel 1. Jumlah Populasi dan Sampel Penelitian Kualitas Laporan Surveyor pada bab Pelayanan Kefarmasian dan Penggunaan Obat Berdasarkan Tingkat Kelulusan Akreditasi RS

\begin{tabular}{lcc}
\hline $\begin{array}{l}\text { Tingkat Kelulusan } \\
\text { Akreditasi RS }\end{array}$ & $\begin{array}{c}\text { Jumlah } \\
\text { Populasi }\end{array}$ & Jumlah Sampel (\%) \\
\hline Paripurna & 397 & $25(39,06 \%)$ \\
Utama & 203 & $12(18,75 \%)$ \\
Madya & 273 & $17(26,56 \%)$ \\
Dasar & 164 & $10(15,62 \%)$ \\
\hline Total & $\mathbf{1 . 0 3 7}$ & $\mathbf{6 4 ( 1 0 0 , 0 0 \% )}$
\end{tabular}

Variabel penelitian meliputi waktu penyampaian laporan, ketepatan pemberian nilai, ketepatan penulisan fakta dan analisis, ketepatan penulisan rekomendasi oleh surveyor dan konselor. Pengumpulan data menggunakan instrumen berupa checklist yang telah dilakukan validasi dan kelaikan etika penelitian oleh jangkar KARS sebagai tenaga ahli dan representasi lembaga KARS. Setelah data terkumpul, dilakukan analisis dengan program SPSS disajikan dalam bentuk data kuantitatif untuk ditarik kesimpulan.

Tabel 2. Sampel Penelitian Kualitas Laporan Surveyor pada bab Pelayanan Kefarmasian dan Penggunaan Obat berdasarkan Wilayah Geografis

\begin{tabular}{|c|c|c|c|c|c|c|c|c|c|}
\hline \multirow[b]{3}{*}{ Wilayah Geografi } & \multicolumn{8}{|c|}{ Tingkat Kelulusan RS } & \multirow{3}{*}{$\begin{array}{c}\text { Jumlah } \\
\text { Sampel } \\
\text { Per } \\
\text { Wilayah }\end{array}$} \\
\hline & \multicolumn{2}{|c|}{ Paripurna } & \multicolumn{2}{|c|}{ Utama } & \multicolumn{2}{|c|}{ Madya } & \multicolumn{2}{|c|}{ Dasar } & \\
\hline & $\begin{array}{c}\text { Jumlah } \\
\text { Populasi }\end{array}$ & $\begin{array}{l}\text { Jumlah } \\
\text { Sampel } \\
\end{array}$ & $\begin{array}{c}\text { Jumlah } \\
\text { Populasi }\end{array}$ & $\begin{array}{l}\text { Jumlah } \\
\text { Sampel }\end{array}$ & $\begin{array}{l}\text { Jumlah } \\
\text { Populasi }\end{array}$ & $\begin{array}{l}\text { Jumlah } \\
\text { Sampel }\end{array}$ & $\begin{array}{l}\text { Jumlah } \\
\text { Populasi }\end{array}$ & $\begin{array}{l}\text { Jumlah } \\
\text { Sampel } \\
\end{array}$ & \\
\hline \multicolumn{10}{|l|}{ Sumatera } \\
\hline Aceh & o & o & 7 & 1 & 6 & o & 5 & o & 1 \\
\hline Sumatra Utara & 16 & 0 & 10 & o & 17 & 3 & 14 & 1 & 4 \\
\hline Sumatra Barat & 6 & 1 & 6 & 1 & 4 & o & 1 & o & 2 \\
\hline Riau & 4 & o & 3 & 1 & 5 & 1 & 2 & o & 2 \\
\hline Kepulauan Riau & 4 & 1 & 2 & 1 & 7 & 1 & o & 0 & 3 \\
\hline Jambi & 10 & 1 & 2 & o & 4 & o & o & o & 1 \\
\hline Bengkulu & 2 & o & 3 & o & 4 & o & 2 & 0 & o \\
\hline Sumatra Selatan & 9 & 2 & 7 & o & 11 & o & 4 & 1 & 3 \\
\hline Kepulauan Bangka Belitung & 3 & o & 3 & 1 & 2 & 1 & 3 & o & 2 \\
\hline Lampung & 6 & 1 & 6 & o & 7 & o & 6 & 1 & 2 \\
\hline \multicolumn{10}{|l|}{ Jawa } \\
\hline Banten & 14 & 1 & 8 & o & 4 & o & 7 & o & 1 \\
\hline Jawa Barat & 51 & 4 & 27 & 2 & 33 & 4 & 21 & 2 & 12 \\
\hline DKI Jakarta & 50 & 1 & 12 & 1 & 20 & 1 & 5 & o & 3 \\
\hline Jawa Tengah & 71 & 5 & 22 & 3 & 15 & 1 & 7 & 2 & 11 \\
\hline Daerah Istimewa Yogyakarta & 15 & 0 & 3 & o & 11 & 1 & 3 & 1 & 2 \\
\hline Jawa Timur & 71 & 4 & 29 & 1 & 44 & 3 & 25 & o & 8 \\
\hline \multicolumn{10}{|l|}{ Bali dan Nusa Tenggara } \\
\hline Bali & 17 & 1 & 5 & o & 6 & o & 6 & o & 1 \\
\hline Nusa Tenggara Barat & 5 & o & o & o & 2 & o & 6 & o & o \\
\hline Nusa Tenggara Timur & 4 & o & 6 & o & 7 & o & 7 & o & o \\
\hline \multicolumn{10}{|l|}{ Kalimatan } \\
\hline Kalimantan Barat & 3 & o & 6 & o & 8 & 1 & 4 & o & 1 \\
\hline Kalimantan Selatan & 2 & o & 2 & o & 6 & o & 3 & o & o \\
\hline Kalimantan Tengah & 2 & o & 4 & o & 3 & o & 1 & o & o \\
\hline Kalimantan Timur & 9 & 1 & 3 & 0 & 5 & o & 4 & 0 & 1 \\
\hline Kalimantan Utara & 0 & o & 0 & o & 1 & o & o & o & o \\
\hline \multicolumn{10}{|l|}{ Sulawesi } \\
\hline Gorontalo & o & 0 & $\mathrm{o}$ & 0 & $\mathrm{o}$ & o & 0 & 0 & o \\
\hline Sulawesi Barat & o & o & o & o & 1 & o & 2 & o & o \\
\hline Sulawesi Selatan & 14 & 1 & 16 & o & 10 & 0 & 5 & 0 & 1 \\
\hline Sulawesi Tengah & 2 & o & 3 & o & 6 & o & 2 & 1 & 1 \\
\hline Sulawesi Tenggara & 2 & 1 & 2 & o & 5 & o & 4 & o & 1 \\
\hline Sulawesi Utara & 1 & o & 3 & o & 6 & o & 5 & o & o \\
\hline \multicolumn{10}{|l|}{ Maluku dan Papua } \\
\hline Maluku & o & o & o & o & 5 & o & 6 & o & o \\
\hline Maluku Utara & 2 & 0 & 0 & 0 & 2 & o & 3 & o & 0 \\
\hline Papua & 2 & 0 & 2 & o & 5 & o & 1 & 1 & 1 \\
\hline Papua Barat & o & o & 1 & o & 1 & o & o & o & o \\
\hline Jumlah & 397 & 25 & 203 & 12 & 273 & 17 & 164 & 10 & 64 \\
\hline
\end{tabular}




\section{Hasil}

Sebagian besar sampel adalah RS lulus paripurna (39,06\%), utama $(18,75 \%)$, madya $(26,56 \%)$, utama $(18,75 \%)$ dan dasar (15,62\%) (Tabel 1). Sampel terbanyak di Jawa Barat dan Jawa Tengah, masing-masing 12 RS dan 11 RS (Tabel 2).

Sedangkan untuk kajian elemen penilaian (EP), jumlah keseluruhan elemen penilaian (EP) yang mendapatkan nilai o dan 5 pada 64 rumah sakit sampel adalah 1.046 EP5. Didapatkan antara 3-43 EP dengan nilai o-5 di masing-masing RS, dengan rata-rata 16 EP setiap RS. Untuk penilaian kualitas laporan hasil survei dilakukan dengan mengevaluasi 5 variabel, yaitu: ketepatan waktu penyampaian laporan, ketepatan pemberian nilai, ketepatan penulisan fakta dan analisis, ketepatan penulisan rekomendasi, dan kejadian diskrepansi antara surveyor dan konselor. Tabel 3 menunjukkan hasil evaluasi kualitas pelaporan hasil survei bab PKPO tahun 2019.

Tabel 3. Kualitas Pelaporan Hasil Survei Bab Pelayanan Kefarmasian dan Penggunaan Obat Tahun 2019

\begin{tabular}{|c|c|c|c|c|}
\hline \multirow[t]{2}{*}{ Kualitas Pelaporan } & \multicolumn{2}{|c|}{$\begin{array}{c}\text { Jumlah dan Proporsi } \\
\text { yang Tepat }\end{array}$} & \multicolumn{2}{|c|}{$\begin{array}{l}\text { Jumlah dan Proporsi } \\
\text { yang Tidak tepat }\end{array}$} \\
\hline & $\mathrm{n}$ & $\%$ & $\mathrm{n}$ & $\%$ \\
\hline Ketepatan waktu penyampaian laporan hasil survei $(n=64)$ & $38 \mathrm{RS}$ & $59,00 \%$ & $26 \mathrm{RS}$ & $41,00 \%$ \\
\hline Ketepatan Pemberian Nilai $(\mathrm{n}=1.046)$ & $739 \mathrm{EP}$ & $71,00 \%$ & $307 \mathrm{EP}$ & $29,00 \%$ \\
\hline Ketepatan Penulisan Fakta dan Analisis ( $\mathrm{n}=1.046)$ & $518 \mathrm{EP}$ & $49,50 \%$ & $528 \mathrm{EP}$ & $50,50 \%$ \\
\hline Ketepatan Penulisan Rekomendasi $(\mathrm{n}=1.046)$ & $429 \mathrm{EP}$ & $41,00 \%$ & $617 \mathrm{EP}$ & $59,00 \%$ \\
\hline Kejadian Diskrepansi & \multicolumn{4}{|c|}{$\begin{array}{l}11 \mathrm{RS} \text { dengan } 168 \mathrm{EP} \text {, diantaranya: } \\
\text { - } \quad 42 \mathrm{EP}(25,00 \%) \text { diskrepansi nilai } \\
\text { - } \quad 12 \mathrm{EP}(7,00 \%) \text { diskrepansi fakta dan analisis } \\
\text { - } \quad 114 \mathrm{EP}(68,00 \%) \text { diskrepansi rekomendasi }\end{array}$} \\
\hline
\end{tabular}

\section{Pembahasan}

Untuk ketepatan waktu pelaporan, rerata jumlah hari laporan adalah 11,6 hari dengan waktu tercepat pelaporan bervariasi antara satu hari (pada 2 rumah sakit sampel) hingga 55 hari. Rerata pelaporan melebihi standar (7 hari) sehingga masih belum memenuhi standar yang ditetapkan. Ketepatan waktu laporan survei sangat tergantung dari peran Ketua Tim Survei (KTS) yang diberi wewenang untuk memberikan persetujuan pada sistem 6 . KTS juga diberi fasilitas sistem untuk mengirim pesan email otomatis kepada anggota surveyor yang belum mengunggah laporan, sehingga kepemimpinan KTS sangat diperlukan7.

Beberapa hal juga dijumpai pada ketepatan pemberian nilai. Misalnya surveyor menyampaikan bahwa belum tersedia bukti atau belum tersedia dokumennya, akan tetapi memberi nilai angka 5. Terkadang dijumpai pula bahwa yang seharusnya tidak diminta oleh standar, ternyata justru diminta oleh surveyor 7 . Sebagai ilustrasi, pada instrumen hanya diminta regulasi, akan tetapi surveyor menyampaikan bahwa regulasi sudah ada namun belum diterapkan sepenuhnya. Sehingga surveyor memberikan nilai 5 yang seharusnya dinilai 10. Ketepatan pemberian nilai 10 tidak dapat diketahui karena tidak dapat dilakukan analisis. Pada penelitian ini, ketepatan pemberian nilai diperoleh sebesar 71,00\% (cukup baik), sekalipun masih dapat ditingkatkan upaya untuk mengoptimalkannya.

Dibandingkan dengan standar emas yang telah disusun, maka ketepatan penulisan fakta dan analisis surveyor mencapai 49,50\% (kurang baik) ${ }^{7}$. Hal ini menunjukkan bahwa meskipun kemungkinan surveyor memiliki kemampuan dalam penulisan fakta dan analisis, menguasai bab PKPO serta memahami link antar standar/EP, namun masih perlu ditingkatkan agar ketepatan penulisan fakta dan analisis lebih baik lagi.
Ketidaktepatan penulisan fakta dan analisis surveyor mencapai 50,50\%. Beberapa hal yang dijumpai dalam ketidaktepatan penulisan fakta dan analisis diantaranya adalah perilaku surveyor melakukan copy paste dari EP yang asli dengan menambahkan kata "belum/tidak ada" di depan kalimat EP8. Selain itu, surveyor menuliskan hal-hal yang di luar persyaratan yang diminta pada standar, penulisan yang tidak jelas karena hanya mencantumkan "tidak ada/belum ada bukti" tanpa subjek yang jelas, surveyor keliru meminta bukti regulasi atau implementasi seperti yang dipersyaratkan pada standar9.

Ketepatan penulisan rekomendasi mencapai 41,00\% (kurang baik), meskipun dalam hal ini surveyor memberikan rekomendasi dengan baik sesuai gold standar dan rekomendasi tersebut dapat dilaksanakan oleh rumah sakit dalam menyusun Perencanaan Perbaikan Strategis 5 . Hal ini mencerminkan bahwa surveyor sangat memahami bab PKPO. Ketidaktepatan rekomendasi mencapai 59,00\%. Beberapa hal yang dijumpai dalam ketidaktepatan penulisan rekomendasi antara lain: surveyor hanya menyalin dari EP yang asli dengan menambahkan kata "lengkapi/buktikan" di depan kalimat EP; surveyor menuliskan hal-hal di luar permintaan standar; penulisan tidak jelas karena hanya menulis "sediakan bukti/buktikan/lengkapi” tanpa subyek yang jelas; surveyor kurang tepat memberi rekomendasi karena yang dipersyaratkan dalam standar adalah regulasi/implementasi, akan tetapi yang disarankan adalah menyediakan implementasi/regulasi ${ }^{8}$.

Terdapat pesan diskrepansi sejumlah 26, dengan diskrepansi terbanyak berkaitan dengan catatan khusus pada PKPO 2 EP 3 (15,00\%), PKPO 2.1 (12,00\%) dengan beberapa catatan. Diskrepansi terjadi pada 168 dari 1.046 EP yang diteliti (17,00\%). Sedangkan ketidaktepatan nilai adalah 25,00\%, ketidaktepatan penulisan fakta dan analisis 7,00\% serta ketidaktepatan pemberian rekomendasi sebesar 68,00\%. Beberapa konselor sudah menuliskan/mengubah penilaian, 
fakta dan analisis serta rekomendasi surveyor yang kurang tepat, bahkan juga menuliskan pesan untuk surveyor, sebagai sarana pembelajaran bagi surveyor. Sebagai ilustrasi pesan masukan untuk surveyor adalah: fakta dan analisis serta rekomendasi tidak hanya menyalin dari $\mathrm{EP}^{9}$; menyarankan bukti pelaksanaan proses pengelolaan yang benar sesuai peraturan; melihat kembali materi PKPO dan RKK perawat.

Pada laporan hasil survei 53 rumah sakit sampel (83,00\%), tidak terdapat diskrepansi maupun pesan dari konselor untuk surveyor terhadap nilai, fakta dan analisis serta rekomendasi. Laporan konselor tidak ada perubahan, meskipun pada laporan laporan tersebut terdapat ketidaktepatan, sehingga laporan yang disampaikan kepada rumah sakit masih sesuai dengan laporan surveyor yang asli.

\section{Kesimpulan}

Kualitas laporan hasil survei akreditasi surveyor manajemen pada bab PKPO tahun 2019 terkait ketepatan laporan hasil survei mencapai 55,10\% (kurang baik). Sebagai tindak lanjut hasil penelitian ini, diperlukan peningkatan pemahaman surveyor dan standarisasi laporan hasil survei terkait penulisan fakta dan analisis serta rekomendasinya tentang PKPO dan RKK perawat.

Selain itu untuk menggali berbagai faktor yang berkontribusi dalam kualitas penulisan laporan hasil survei akreditasi, dapat dilaksanakan penelitian lebih lanjut seperti penelitian kualitatif. Sehingga dapat teridentifikasi berbagai faktor yang berperan dalam capaian kualitas penulisan laporan hasil survei tersebut, yang tidak dapat dipaparkan dalam penelitian kuantitatif.

\section{Referensi}

1. Yunirtha L. Komisi Akreditasi Rumah Sakit Janji Percepat Akreditasi Rumah Sakit. Diakses dari https://nasional. kontan.co.id/news/komisi-akreditasi-rumah-sakit-janji-percepatakreditasi-rumah-sakit

2. Yousefinezhadi T, Mosadeghrad AM, Hinchcliff R, dkk. Evaluation Results of National Hospital Accreditation Program in Iran: The View of Hospital Managers. Journal of Healthcare Quality Research Volume 35 Issue 1. January-February 2020; Pages 12-18.

3. Teymourzadeh E, Ramezani M, Arab M, dkk. Surveyor Management of Hospital Accreditation Program: A Thematic Analysis Conducted in Iran. Iran Red Crescent Med J. 2016 Jan $11 ; 18(5)$.

4. Peraturan Menteri Kesehatan Nomor 34 tahun 2017 tentang Akreditasi Rumah Sakit. Kementerian Kesehatan RI. Jakarta; 2017.

5. Instrumen Standar Nasional Akreditasi Rumah Sakit. Komisi Akreditasi Rumah Sakit. Jakarta; 2018.

6. Joint Commission International. Joint Commission International Accreditation Standard for Hospital, $5^{\text {th }}$ ed. Illinois; 2013.

7. The International Society in Healthcare. ISQua Guidelines and Principles for the Development of Health and Social Care Standards 5th Edition v1.o. Illinois; 2010.

8. The International Society in Healthcare. Guidelines and Standards for External Evaluation Organization, $5^{\text {th }}$ ed. Illinois; 2018.

9. Bohigas L, Brooks T, Donahue T, dkk. A Comparative Analysis of Surveyors from Six Hospital Accreditation Programmes and A Consideration of the Related Management Issues. Int J Qual Health Care. 1998 Feb;10(1):7-13. 